\title{
Persepsi Masyarakat Tentang Perempuan Bercadar
}

\author{
Indra Tanra
}

\author{
Nursalam \\ Universitas Muhammadiyah Makassar \\ nursalam@unismuh.ac.id
}

\author{
Syarifuddin \\ Universitas Muhammadiyah Makassar \\ syarifuddin@unismuh.ac.id
}

\begin{abstract}
ABSTRAK
Penelitian tentang Persepsi Masyarakat Tentang Perempuan Bercadar ( studi kasus Desa To'bia Kabupaten Luwu). Tujuan penelitian ini adalah untuk mengetahui persepsi madayarakat tentang peremepuan bercadar di Desa To'bia Kabupaten Luwu.Jenis penelitian ini adalah penelitian sosial budaya (PSB) dengan tipe kualitatif, yaitu prosedur penelitian yang diamati menghasilkan kata-kata tertulis atau lisan dari kelompok petani yang diamati selama melakukan penelitian ini.Dasar penelitian yang digunakan adalah studi kasus yaitu tipe pendekatan dalam penelitian yang penelaahannya kepada satu kasus yang dilakukan secara intensif, mendalam, mendetail, dan komperehensif. Sedangkan Tipe penelitian yang digunakan dalam penelitian ini adalah deskriptif kualitatif dimana penelitian ini bertujuan untuk memberikan gambaran nyata, dan penjelasan tentang persepsi masayarakat tentang perempuan bercadar di Desa To'bia Kabupaten luwu.Pengumpulan data dalam penelitian ini dilakukan dengan cara observasi, wawancara dan dokumentasi.. Hasil penelitian menunjukkan bahwa persepsi masayarakat terhadap perempuan bercadar itu sanagat negatif dan juga mereka tidak menerima adanya perempuan bercadar di Desa mereka, bahkan sebagian masayarakt mengucilkan atau bahkan menolak keberadaan mereka dan mereka tidak di anggap di dalam masayarakat.
\end{abstract}

Kata Kunci: Persepsi, Masyarakat, Perempuan Bercadar.

\section{PENDAHULUAN}

Agama merupakan pedoman hidup manusia dalam kehidupan manusiadalam mengatasi masalah yang dihadapi sehingga dapat mendamaikan lahir dan batin manusia agama sebagai tolak ukur manusia dalam menbentuk kepribadian dan perilaku yang berfungsi untuk memahami dan saling mengerti antar umat beragama dalam setiap individu. Pemahaman antar yang baik dan buruk, yang benar dan yang salah pemahaman antar yang boleh dan tidak boleh dilakukan karena ajaran agama menentukan sistem kepercayaan sehingga tidak heran lagi apabila suatu waktu konsep agama turut andil dalam menentukan prilaku manusia terhadap apa yang mereka lihat dan apa yang mereka lakukan.

Agama merupakan entitas yang diyakini.Agama dipercaya mampu menberikan dorongan dan menebarkan kebahagian yang memaksa manusia mencari dan mengharap 
kebahagian di surga. Agama mampu mengarahkan kebebasan manusia yang diambil dan menentukan diberikan kepada sesuatu yang bernama Tuhan akibatnya yang terjafi adalah hilangnya kebebasan berpikir yang ditundukan kepada keimanan, wahyu dan moralitas.

Fenomena yang terjadi saat ini banyak perempuan yang memakai cadar dikalangan muslimah, menurut Shihab (dalam Mailani, 2013) cadar dalam Islam adalah jilbab yang tebal dan longgar yang menutup semua aurat termasuk wajah dan telapak tangan.Dasar dari penggunaan cadar adalah untuk menjaga perempuan sehingga tidak menjadi fitnah dan menarik perhatian laki-laki yang bukan mahramnya.

Bahwa memakai cadar (dan juga jilbab) bukanlah sekedar budaya TimurTengah, namun budaya Islam dan ajaran Islam yang sudah diajarkan oleh para ulama Islam sebagai pewaris para nabi yang memberikan pengajaran kepada seluruh umat Islam, bukan kepada masyarakat Timur-Tengah saja. Jika memang budaya Islam ini sudah dianggap sebagai budaya lokal oleh masyarakat timur-tengah, maka tentu ini adalah perkara yang baik. Karena memang demikian sepatutnya, seorang muslim berbudaya Islam.

Keberadaan perempuan bercadar masih belum dapat diterima secara penuh oleh masyarakat, terdapat persepsi negatif dari masyarakat penggunaan cadar yang dilakukan para perempuan tersebut menganggu proses hubungan antar pribadi di dalam masyarakat. masayarakat juga beranggapan bahwa perempuan yang memakai cadar itu hanya kedok belaka mereka beranggapan bahwa perempuan yang memakai cadar adalah teroris atau penganut aliran sesaat dan ada pula sebagian masyarakat yang beranggapan bahwa perempuan bercadar tidak mau bersosialisasi dengan masyarakat lainnya, bahkan ada masyarakat yang menggagap cadar hanya alat untuk menutup-nutupi kejelekanya. Selama sebab-sebab perbedaan pendapat itu masih ada, maka ikhtilaf (perbedaan pendapat) itu akan senantiasa ada diantara manusia, meskipun mereka sama-sama muslim, patuh pada agamanya, dan ikhlas. Bahkan kadang-kadang komitmen dan keikhlasan terhadap agama menyebabkan perbedaan pendapat itu semakin tajam. Masing-masing pihak ingin mengunggulkan dan memberlakukan pendapat yang diyakininya benar sebagai ajaran agama yang akan diperhitungkan dengan mendapatkan pahala (bagi yang melaksanakannya) atau mendapatkan hukuman (bagi yang melanggarnya).

Perbedaan pendapat itu akan terus berlangsung selama nash- nashnya sendiri yang merupakan sumber penggalian hukum masih menerima kemungkinan perbedaan pendapat tentang periwayatan dan petunjuknya, selama pemahaman dan kemampuan manusia untuk mengistimbath (menggali dan mengeluarkan) hukum 
masih berbeda-beda, dan sepanjang masih ada kemungkinan untuk mengambil zhahir nash atau kandungannya, yang tersurat atau yang tersirat, yang rukhshah (merupakan keringanan) ataupun yang 'azimah (hukum asal), yang lebih hati-hati atau yang lebih mudah.

\section{LANDASAN TEORI}

Istilah persepsi sering disebut juga disebut juga dengan pandangan, gambaran, atau anggapan, sebab dalam persepsi terdapat tanggapan seseorang mengenai satu hal atau objek. dalam kamus besar psikologi, persepsi diartikan sebagai suatu proses pengamatan seseorang terhadap lingkungan dengan menggunakan indra-indra yang dimiliki sehingga ia menjadi sadar akan segala sesuatu yang ada dilingkungannya. Persepsi merupakan salah satu aspek psikologis yang penting bagi manusia dalam merespon kehadiran berbagai aspek dan gejala di sekitarnya. Persepsi mengandung pengertian yang sangat luas, menyangkut intern dan ekstern. Berbagai ahli telah memberikan definisi yang beragam tentang persepsi, walaupun pada prinsipnya mengandung makna yang sama. Menurut Kamus Besar Bahasa Indonesia, persepsi adalah tanggapan (penerimaan) langsung dari sesuatu. Proses seseorang mengetahui beberapa hal melalui panca inderanya.

Sugihartono, dkk (2007: 8) mengemukakan bahwa persepsi adalah kemampuan otak dalam menerjemahkan stimulus atau proses untuk menerjemahkan stimulus yang masuk ke dalam alat indera manusia. Persepsi manusia terdapat perbedaan sudut pandang dalam penginderaan. Ada yang mempersepsikan sesuatu itu baik atau persepsi yang positif maupun persepsinegatif yang akan mempengaruhi tindakan manusia yang tampak atau nyata.

Masyarakat (sebagai terjemahan istilah society) adalah sekelompok orang yang membentuk sebuah sistem semi tertutup (atau semi terbuka), dimana sebagian besar interaksi adalah antara individu-individu yang berada dalam kelompok tersebut.Kata "masyarakat" sendiri berakar dari kata dalam bahasa Arab, musyarak.Lebih abstraknya, sebuah masyarakat adalah suatu jaringan hubungan-hubungan antar entitas-entitas. Masyarakat adalah sebuah komunitasyang interdependen (saling tergantung satu sama lain). Umumnya, istilah masyarakat digunakan untuk mengacu sekelompok orang yang hidup bersama dalam satu komunitas yang teratur. Masyarakat sering diorganisasikan berdasarkan cara utamanya dalam bermata pencaharian. Pakar ilmu sosial mengidentifikasikan ada: masyarakat pemburu, masyarakat pastoral nomadis, masyarakat 
bercocoktanam, dan masyarakat agrikultural intensif, yang juga disebut masyarakat peradaban. Sebagian pakar menganggap masyarakat industri dan pasca-industri sebagai kelompok masyarakat yang terpisah dari masyarakat agrikultural tradisional. Masyarakat dapat pula diorganisasikan berdasarkan struktur politiknya: berdasarkan urutan kompleksitas dan besar, terdapat masyarakat band, suku, chiefdom, dan masyarakat negara.

Community dalam bahasa yunani adalah "persahabatan". Sebagai refleksi dari arti kata tersebut, aristoteles mengemukakan bahwa manusia yang hidup bersama dalam masyarakat karena mereka menikmati ikatan yang saling bekerja sama, untuk memenuhi kebutuhan dasar mereka dan untuk menemukan makna kehidupan.

Jilbab, secarik kain untuk menutupi kepala dan rambut perempuan, tak lagi menjadi masalah sederhana.Jilbab menyuguhkan kepada kita dua konteks yang berbeda dan saling bertentangan.Suatu waktu, mengenakan jilbab diperlukan usaha keras karena ada yang melarangnya.Namun, di sisi lain, pemakaian jilbab justru dipaksakan.Misalnya pegawai perempuan di Jakarta mengalami kesulitan dengan pihak manajemen karena mereka memakai jilbab.Demikian juga di beberapa negara di Eropa, khususnya di Prancis, yang saat ini menerapkan pelarangan pemakaian simbol-simbol agama di tempat umum tak hanya simbol Islam.Contoh di atas adalah untuk memperlihatkan betapa persoalan jilbab ini sudah dipandang secara hitam-putih.Lebih dari itu, ada semacam ketakutan yang berlebihan dari dua arus tersebut. Apabila hal ini sengaja didiamkan, jilbab akan dimusuhi dan akan terus-menerus dilarang oleh mereka yang membenci. Sebaliknya, mereka yang mendukung jilbab akan terus memperjuangkannya. Saya kira, di sinilah letak pentingnya mendiskusikan kembali fenomena jilbab.Pihak yang setuju ataupun menolak harus menyadari bahwa jilbab, sebagai fenomena, membawa pesan yang beragam. Menganut satu persepsi saja terhadap fenomena jilbab ini akan menjerumuskan kita pada bentuk penghakiman yang sewenang-wenang. Keputusan apa pun yang diambil, bila berasal dari asumsi yang salah, tak akan pernah bisa menyelesaikan masalah, malah akan menimbulkan masalah yang jauh lebih besar.

Di kalangan masyarakat sekarang terutama di Desa To'bia banyak perempuan yang menutup aurat dengan cara memakai cadar sehingga masyarakat disana banyak yang berangggapan bahwa perempuan yang memakai cadar itu aliran sesat, teroris. Sehingga keberadaan mereka dikalangan masyarakat tidak dapat diterima oleh masyarakat bahkan keluarganya sendiri karena mereka kurang berinteraksi dan berkomunikasi dengan 
masyarakat sekitar sehingga persepsi masyarakat tentang mereka itu di perkuat dengan tingkah laku mereka sendiri.

Adapun teori yang digunakan dalam membahas penelitian ini yaituDari konsep yang telah tertera diatas maka penelitian ini menggunakan teori interaksionisme simbolik yang dikemukakan oleh Herbert Mead, dasar dari interaksionisme simbolik sebanarnya tak mudah menggolongkan pemikiran ini kedalam teori dalam artian umum karena seperti dikatakan Paul Rock, pemikiran ini sengaja di bangun secara samar dan merupakan resistensi terhadap sistematisasi. Ada beberapa perbedaan signifikan dalam interaksionisme simbolik. Pembelajaran mengenai makna dan simbol Mead mengatakan, teoritisi interaksionisme simbolik cenderung menyetujui pentingnya sebab musabab interaksi sosial. Dengan demikian, makna bukan berasal dari proses mental yang menyendiri, tetapi berasal dari interaksi. Tindakan dan interaksi manusia, bukan pada proses mental yang terisolasi, bukan bagaimana cara mental manusia menciptakan arti dan simbol, tetapi bagaimana cara mereka mempelajarinya selama interaksi pada umumnya dan selama proses sosialisasi pada khususnya.

Kemudian yang kedua yaitu teori Teori Indentitas dikemukakan oleh Sheldon Stryker (1980).Teori ini memusatkan perhatiannya pada hubungan saling mempengaruhi di antara individu dengan struktur sosial yang lebih besar lagi (masyarakat).Individu dan masyarakat dipandang sebagai dua sisi dari satu mata uang.Seseorang dibentuk oleh interaksi, namun struktur sosial membentuk interaksi.Dalam hal ini Stryker tampaknya setuju dengan perspektif struktural, khususnya teori peran. Namun dia juga memberi sedikit kritik terhadap teori peran yang menurutnya terlampau tidak peka terhadap kreativitas individu.Seperti yang terjadi di masyarakat desa To'bia yang kalangan maasyarakatnya hanya sibuk untuk memperlihatkan identitas mereka, mereka ingin diakui keberadaannya di kalangan masyarakat tanpa memikirkan bagaimana pandangan masyarakat terhadap mereka, apakah itu baik atau buruk meraka menyampingkan hal tersebut asalkan keinginan mereka tercapai atau terwujud.

\section{METODE PENELITIAN}

Jenis penelitian yang dilakukan adalahjenis penelitian kualitatif, meliputi rangkaian kegiatan yang sistematik untuk mendapatkan jawaban atas permasalahan yang diajukan.Jika dilihat dari jenis dan obyek yang diteliti, maka penelitian ini dikategorikan sebagai penelitian studi kasus dengan maksud memberikan gambaran tentang Persepsi Masyarakat terhadap perempuan bercadar desa Tobi'a Kabupaten Luwu. Informan ditentukan secara purposive sampling, fokus penelitian yaitu persepsi masyarakat terhadap 
perempuan bercadar di Desa Tobi'a Kabupaten Luwu. Yang bertindak sebagai instrumen penelitian adalah peneliti sendiri dengan menggunakan alat bantu berupa pedoman wawancara (daftar pertanyaan), pedoman observasi, pensil/pulpen dan catatan peneliti yang berfungsi sebagai alat pengumpul data serta alat pemotret dan catatan peneliti,teknik pengumpulan data yaitu observasi, wawancara, dan dokumentasi, kemudian dianalisis melalui tahap reduksi data, penyajian data, lalu kemudian penarikan kesimpulan. Adapun teknik keabsahan data untuk lebih mudah mempertanggungjawabkan hasil penelitian di lapangan yaitu dengan menggunakan yaitu dengan mengunakan metode triangulasi yakni triangulasi sumber, triangulasi teknik, dan triangulasi waktu.

\section{PEMBAHASAN}

Banyak faktor yang membuat perempuan di desa To'bia bercadar itu bisa dari dalam dirinya maupun dari luar dirinya. banyak diantara mereka yang memakai cadar itu berasal dari kesadarannya sendiri ada juga yang dari dorongan orang lain atau dengan kata lain dari luar dirinya sendiri Menurut Terry (1989) faktor-faktor yang harus diperhatikan dalam mengambil keputusan sebagai berikut: hal-hal yang berwujud maupun tidak berwujud, yang emosional maupun rasional perlu diperhitungkan dalam pengambilan keputusan;setiap keputusan nantinya harus dapat dijadikan bahan untuk mencapai tujuan organisasi; setiap keputusan janganlah berorientasi pada kepentingan pribadi, perhatikan kepentingan orang lain; jarang sekali ada 1 pilihan yang memuaskan; pengambilan keputusan merupakan tindakan mental. Dari tindakan mental ini kemudian harus diubah menjadi tindakan fisik; pengambilan keputusan yang efektif membutuhkan waktu yang cukup lama; diperlukan pengambilan keputusan yang praktis untuk mendapatkan hasil yang baik; setiap keputusan hendaknya dikembangkan, agar dapat diketahui apakah keputusan yang diambil itu betul; dan setiap keputusan itu merupakan tindakan permulaan dari serangkaian kegiatan berikutnya.

Kemudian terdapat enam faktor lain yang juga ikut mempengaruhi pengambilan keputusan. (1). Fisik: Didasarkan pada rasa yang dialami pada tubuh, seperti rasa tidak nyaman, atau kenikmatan. Ada kecenderungan menghindari tingkah laku yang menimbulkan rasa tidak senang, sebaliknya memilih tingkah laku yang memberikan kesenangan. (2). Emosional: Didasarkan pada perasaan atau sikap. Orang akan bereaksi pada suatu situasi secara subjective. (3). Rasional: Didasarkan pada pengetahuan orangorang mendapatkan informasi, memahami situasi dan berbagai konsekuensinya. (4). Praktikal: Didasarkan pada keterampilan individual dan kemampuan melaksanakan. 
Seseorang akan menilai potensi diri dan kepercayaan dirinya melalui kemampuanya dalam bertindak. (5). Interpersonal: Didasarkan pada pengaruh jaringan sosial yang ada. Hubungan antar satu orang keorang lainnya dapat mempengaruhi tindakan individual. (6). Struktural: Didasarkan pada lingkup sosial, ekonomi dan politik. Lingkungan mungkin memberikan hasil yang mendukung atau mengkritik suatu tingkah laku tertentu.

Dilihat dari wawancara dan juga observasi bahawa faktor yang menbuat masyarakat bercadar itu juga dapat di pengaruhi oleh lingkungan sendiri dengan adanya respon yang poertama kali memakai cadar itu karena terpaksa oleh suami sendiri dan juga karena tuntutatan organisasi yang menbuat mereka bercadar tapi lama kelamaan mereka memakai cadar itu karena dirinya sendir bukan lagi karena paksaan orang lain, karen merak juga berinteraksi dengan masyarakat lain yang menbuat mata mereka bahwa menutup aurat atau bercadar itu adalah hal yang indah bukan lagi hal yang tidak dapat diterima oleh pikiran hati seseorang dan juga memakai cadar itu menbuat seorang perempuan bila keluar rumah itumerasa aman dan nayaman dalam melakukan hal, tanpa ada rasa takut lagi terhadap orang lain.

Persepsi : merupakan suatu proses yang didahului oleh penginderaan, yaitu suatu stimulus yang diterima oleh individu melalui alat reseptor yaitu indera. Alat indera merupakan penghubung antara individu dengan dunia luarnya. Persepsi merupakan stimulus yang diindera oleh individu, diorganisasikan kemudian diinterpretasikan sehingga individu menyadari dan mengerti tentang apa yang diindera.

Manusia hidup tidak lepas dari kehidupan kelompok, baik kelompok kecil maupun kelompok besar.maka daripada itu setiap individu pula memiliki persepsi masing-masing dalam menyikapi sesuatu ada yang berpresepsi yang baik ada pula buruk bagi seseorang itu tergantung siapa dan dimana individu atau masyarakat tersebut menberikan tanggapan. Banyak faktor Faktor-faktor yang mempengaruhi persepsi pada dasarnya dibagi menjadi 2 yaitu Faktor Internal dan Faktor Eksternal.Faktor Internal yang mempengaruhi persepsi, yaitu faktor-faktor yang terdapat dalam diri individu, Faktor Eksternal yang mempengaruhi persepsi, merupakan karakteristik dari linkungan dan obyek-obyek yang terlibat didalamnya. Elemen-elemen tersebut dapat mengubah sudut pandang seseorang terhadap dunia sekitarnya dan mempengaruhi bagaimana seseoarang merasakannya atau menerimanya. Dilihat dari wawancara dan juga obseravsi yang dilakukan maka dapat disimpulkan bahwa persepsi masyarakat di Desa To'bia terhadap perempuan bercadar itu sangat negtif atau dengan kata lain mereka tidak diterima di tengah-tengah masyarakat karena masyarakat menganggap mereka seperti anggota teroris 
atau bahkan pengikut aliran sesat. Perempuan bercadar didesa tersebut di kucilkan atau bahkan tak di anggap sebagian masyarakat tentang keberadaan mereka. Karena mereka sanagat menonjol bukan hanya karena cara berpakaiananya yang berbeda dengan masyarakat lain tetapi juga dengan sifat, sikap dan kelakukannya yang sangat tertutup dan bahkan menghindari masayarakat.

\section{KESIMPULAN}

1. Faktor penyebab yang membuat perempuan di desa To'bia bercadar yaitu adanya kesadaran dari diri individu bahwa menutup aurat itu di wajibkan atau di haruskan dalam agama, mereka juga beranggappan bahwa memakai cadar juga salah satu cara untuk menutup aurat, ada juga penyebab mereka memakai cadar karena pengaruhi dari luar seperti paksaan oleh suami sendiri dan juga karena tuntutan organisasi yang membuat mereka bercadar tapi lama kelamaan mereka memakai cadar itu karena dirinya sendiri bukan lagi karena paksaan orang lain, karena meraka juga berinteraksi dengan masyarakat lain yang membuat mata mereka terbuka bahwa menutup aurat atau bercadar itu adalah hal yang indah bukan lagi hal yang tidak dapat diterima oleh pikiran, hati seseorang dan juga memakai cadar itu membuat seorang perempuan bila keluar rumah itu merasa aman dan nyaman.

2. Persepsi masyarakat terhadap perempuan bercadar yaitu sangat negatif karena mereka tidak diterima, dikucilkan bahkan tidak di anggap oleh masyarakat dan juga keluarganya sendiri. Perempuan yang memakai cadar juga di identikan dengan teroris dan juga penaganut aliran sesaat yang marak terjadi saat ini dan perempuan memakai cadar juga sangat tertutup dan kurang berinteraksi dengan masayarakat lainnya, sehingga hal tersebut menperkuat persepsi masyarakat terhadap mereka karena masyarakat menganggap mereka menutup-nutupi perbuatan mereka.

\section{DAFTAR PUSTAKA}

Al Kasmiri. (2007). Hukum Memakai Jilbab.( Online) (http;// edukasi. kompasiana. com/ 2015 /03 /0/komponen sikap, diakses pada tanggal 27 Maret 2015)

Amili, Usaili. (2000). Nikmatnya Berjilbab. Jakarta, Pustaka Zahra

Arina,Qanita. (2002). Jilbab dan Hijab. Jakarta : Bina Mitra Prees

Black, James \& J. Champion Dean. (1992). Metode dan Masalah Penelitian Sosial.Bandung. PT. Eresco 
Devi, Hardiana. (2012). Persepsi, Sikap Dan Nilai.Malang : Bina Aksa

Guindi El Fedwa. (2004). Jilbab: Pakaian Wanita Muslimah (Pandangan Ulama). Jakarta: Lentera

George Ritzer \&Douglas. (2007) . teori interaksi simbolik .(Online) (http://www. kompasiana. com/hasminee, dikases pada tanggal 20 maret)

Haryono. (2012). Persepsi Menurut Ahli. Bandung : Remaja Rosdakarya

Hendria, (2012) Faktor-faktor persepsi .(online) (http://hendriansdiamond. blogspot. com/2012/01/ choice- menurut- terry-1989-faktor-faktor.html, Diakses pada tanggal 25 maret)

Hendria. (2012) .Nilai-nilai dan Jenis-jenis.(online)( http; //hendriansduanmond. blogspot. com/2012/01/ nilai-nilai dan jenis-jenis pengambilan. html . diakses 20 Maret 2015)

Istiqamah. (2012) ,Motivasi berjilbab Mahasiswa,Salatiga.Sekolah tinggi agama islam Negeri (STAIN) Salatiga( Online, diakses 26 Maret 2015)

Kiswan. (2013). Persepsi. Jakarta:Bina Kencana

Moleong, Lexy J. (2002). Metodologi Penelitian Kualitatif. Bandung: Remaja Rosdakarya

Muhammad. (2002). Indahnya Berhias. Jakarta: Darul Haq

Muhajir. (1996). Metode Penelitian . Bandung : Surakarya

Nashiruddin.(2010). Kriteria Busana Muslimah.Jakarta : Pustaka Imam Asy-Syafi'I

Nurhani.(2011). persepsi mahasiswa semester satu prodi bimbingan konseling Islam Jurusan Dakwah STAIN Pontianak Terhadap Wanita Berjilbab Besar.Pontianak. STAIN Sekolah tinggi agama islam Negeri (STAIN) Pontianak( Online, diakses 25 Maret 2015)

Robbin.(2003). pengertian persepsi.(online) (http;//id.wikipedia.org/wiki//persepsi, diakses pada tanggal 23 maret)

Slameto. (2010). pengertian persepsi.(online) (http;//id.wikipedia.org/wiki//persepsi, diakses pada tanggal 23 maret)

Shihab, M. Quraish. (2004). Jilbab: Pakaian Wanita Muslimah (Pandangan Ulama Masa Lalu dan Cendekiawan Kontemporer). Jakarta: Lentera Hati

Sugiyono.(2014). Metode Penelitian Kuantitif, Kualitatif dan $R$ dan D. Bandung : Alfabeta

Soehartono. (2002). Metode Penelitian Kuantitati dan Kualitatif. Jakarta: Remaja Karya. 
Sofi Amalia. (2013). Kontruksi Identitas Muslimah Bercadar. Jakarta (Online, diakses pada tanggal 24 Maret 2015)

Tahir.(2014). Metodologi Penelitian. Makassar: Univarsitas Muhammadiyah Makassar

Tim Penyusun FKIP Unismuh .(2013). Pedoman Penulisan Skripsi. Makassar: Unismuh Makassar

Terry. (1989) .Faktor-faktor persepsi .(online) (http://hendriansdiamond. blogspot. com/2012/01/ choice- menurut- terry-1989-faktor-faktor.html, Diakses pada tanggal 25 maret)

Prasetia, Heru. (2009). Pakaian, Gaya dan Identitas Perempuan Islam. Srinthil Kajian Perempuan Multikultural edisi 017. Depok: Desantara Foundation

Purwantoro.(1990). pengertian persepsi. (online) (http;// id. wikipedia. org/wiki//persepsi, diakses pada tanggal 23 maret)

Zakiyah Jamal.(2013), Fenomena Wanita Bercadar.Jawa Timur, Universitas Pembangunan Nasional (VETERAN) 